\title{
IMPACT OF SELECTED \\ CORPORATE GOVERNANCE DETERMINANTS \\ ON CORPORATE SOCIAL RESPONSIBILITY REPORTING \\ IN SLOVAK INSURANCE COMPANIES
}

\author{
Janka Grofč́iková ${ }^{2}$ \\ Katarína Izáková ${ }^{3}$ \\ Dagmar Škvareninová 4
}

DOI: https://doi.org/10.31410/ERAZ.S.P.2019.47

\begin{abstract}
Corporate governance (CG) creates important signals that the company sends to its surroundings. It affects the performance of the company and consequently the satisfaction of owners and employees, the trust of creditors, clients and all other interest groups. There are several ways to gain their trust and satisfaction. One of them is to present information on financial support for activities of corporate social responsibility (CSR). The application of CSR in practice is all the more important in companies providing insurance services, which are often referred to in the literature as trust-based products. There is little attention paid to the research of corporate governance in relation to CSR in insurance companies. Therefore, in our paper, we examine the impact of selected determinants of corporate governance on CSR information disclosure in insurance companies based in Slovakia. We use the basic methods of regression and correlation analysis to quantify this relationship. The selection of explanatory determinants of CG is carried out in accordance with the assumption of stakeholders' theory of management. The goal is to find out which set of variables will better explain the impact of corporate governance on CSR reporting. We test the financial and non-financial determinants of CG separately for each party. We are looking for the best model for explaining the influence these parties have on reporting of CSR information.
\end{abstract}

Keywords: Corporate governance, corporate social responsibility, insurance companies.

\section{INTRODUCTION}

$\mathrm{T}$ he importance of the insurance industry for all segments of the economy is undeniable, since it results from its ability to mitigate unfavorable financial situation of individuals and businesses that arises as a result of negative events. The main role of the insurance industry is raising funds for the efficient coverage of risk. Therefore, trust in the clients by insurance companies is crucial. As a matter of course, insurance companies are expected to set the right standards for CG and CSR to be able to build this trust and keep their clients loyal. It is recommended to treat CG and CSR as two sides of the same coin, as it motivates companies to do their business with respect to the benefit of the whole society. At present, companies are more aware of the importance of their "goodwill", which is closely associated to CSR. According to surveys, companies that apply this concept are more successful in the long run. Insurance companies in the SR, as members of their parent multinational companies, follow the rules and policies of

2 Department of Finance and Accounting, Faculty of Economics, Matej Bel University in Banská Bystrica, Tajovského 10, 97590 Banská Bystrica, Slovakia

3 Department of Finance and Accounting, Faculty of Economics, Matej Bel University in Banská Bystrica, Tajovského 10, 97590 Banská Bystrica, Slovakia

4 Department of Finance and Accounting, Faculty of Economics, Matej Bel University in Banská Bystrica, Tajovského 10, 97590 Banská Bystrica, Slovakia 
CSR, and thus contribute to their sustainable development and the development of the whole society. Specificities of CG have been studied by some authors. Apparently, with regard to systemic importance, their studies mainly focus on CG in the banking sector. Among them, [2], [6] examined CG and management of banks in the period before and after the financial crisis. Although the banking and insurance sectors are closely interconnected, the aspects of CG in insurance have yet to be investigated to a sufficient range. These issues are, however, partly examined in the work of [27]. Her work is devoted to seeking comprehensive and systematic insight into academic studies which are focused on analyzing recent legislation and interventions in the field of management and corporate governance in insurance.

In our paper we will try to interconnect these basic concerns. We will examine selected key determinants of $\mathrm{CG}$ and management of companies operating in the insurance sector in terms of two basic approaches to company management. Consequently, we will assess their impact on CSR. Therefore, the aim of our study is to examine the impact of selected CG and financial performance determinants on CSR reporting in insurance companies in Slovakia.

\section{LITERATURE REVIEW}

The importance of management and CG of companies have been investigated by several authors, e. g. [10], [28], [21] and others. However, they mainly focus on enterprises operating in the non-financial sphere. The concept of CG indicates the system by which companies are managed and controlled. With regard to this concept, the role of shareholders is to appoint the Director and auditors as well as to establish supervision to ensure that appropriate control structures are implemented [9]. [24] further completes this argument since he assumes that the application of CG principles, alongside the impact on innovation potential, also has an impact on business performance. CG research from different points of view and in different countries is exploring [32], [16], [17], [30], [14], [31], [22], [4], [19], [5], [26].

Institutions also deal with CG issues. One of them is the OECD. In 1999, this organization developed the first set of CG principles, which was subsequently revised and supplemented in 2004 and 2015. The current valid version was developed in cooperation with the OECD and G20 [15]. This document consists of 6 separate chapters. In the Slovakia, compliance with the principles of CG that relate to insurance companies is also regulated by Act [1], in which is implementing The European frame Solvency II.

The principles of CSR are purposefully integrated into EU strategic documents, (e.g. [12]) and are supported by many international organizations of the United Nations, OECD and governmental organizations, as part of the concept of sustainable global development. [23] concludes that the rhythm and pace of CSR growth varies across continents, countries, sectors and businesses. According to [8], corporate responsibility is a commitment of entrepreneurs to pursue the strategies and to make the decisions or carry out activities that are desirable from the point of view of the company's goals and values. [20] treat CSR as a separate field that exists alongside the company's management, but in any case, there is a close link between these two fields. They conclude that CSR includes economic, legal, ethical and philanthropic (charitable) responsibilities that society expects from the enterprise. Through the level of social responsibility, the company demonstrates its sensitive approach to society problems and at the same time it indicates the quality of cooperation with stakeholders. [11] and [7] analyze how business entities benefit from the policies of CSR. 
The focus of CSR is to build relationships in order to involve all stakeholders in business activities and projects. Additionally, this concept also includes human resources, formal and legal conditions, and the protection of the environment on a voluntary basis. The aspects of CSR are basically defined in seven major areas: (1) CG, (2) employee behavior, (3) human rights, (4) integrity in customer relationships, (5) the environment, (6) business integrity, and (7) social obligations.

Within the assessment and reports on CSR, the Triple Bottom Line (TBL) concept is used by [13]. Three "P" mean Profit - (Economic Prosperity), People - (Social Capital - based on measurement of CSR activities of the company), Planet - (Environmental Component). Measurement of the "performance" of a CSR by TBL is through the relative objective quantification of indicators in several areas, as reported by [25].

In this paper, the "performance" of insurance companies in Slovakia that funded areas of CSR was monitored. These include education (traffic education, training for young people or experts, other assistance and support in education); health (support for cancer, protection and prevention of health); sports (support for selected sports, sports club, support for sport development); humanitarian aid ( safe environment, sheltered workshops for disadvantaged groups, orphanages, schools, kindergartens); employees (programs for employees, employee loans, employee training, motivational programs); environment (environmental protection), R\&D support and cultural events.

\section{METHODOLOGY}

This paper presents the results of research that focuses on the impact of selected corporate governance determinants on CSR reporting in Slovak insurance companies. In accordance with the records of the National Bank of Slovakia, there were 16 insurance companies headquartered in the SR and 22 branches of foreign insurance companies operating in the SR as of 31.12.2017. In compliance with the valid legislation, branches of foreign insurance companies are not obliged to establish management bodies, which are in the joint-stock companies represented by the Board of Directors and the Supervisory Board. The subjects of our research are, among other things, the corporate governance bodies. Therefore, our sample will consist of insurance companies that are based in the SR and set up by the governing bodies according to the law. One insurance company was excluded from the original set, because it was declared bankrupt in January 2018. Taking a statistical point of view into consideration, these entities form a basic set. All the insurance companies included in the research had established a dualistic inner structure system. We got all necessary information from the annual reports on 2017.

The dependent variable in our research is CSR disclosure (CSRD). We examined 26 reported social responsibility parameters in total. These are divided into 8 groups, namely: education (5 parameters), health (3), sports (5), humanitarian aid (5), employees (4), the environment (1), science and research (2) and culture (1 parameter). We have calculated the CSRD index for each insurance company as the ratio of the reported CSR information to the total number of monitored information, expressed as:

$$
C S R D \text { Index }_{i}=\frac{\sum_{d=1}^{26} C S R_{d_{i}}}{\sum C S R_{d}}
$$


where: $\mathrm{i}=$ the insurance company, $\mathrm{CSR}_{\mathrm{di}}=$ the monitored CSR parameter in the insurance company " $\mathrm{i}$ ", the binary coding was used in this case (code 1 denotes the case when the parameter was reported, code 0 denotes the case when the insurance company did not report the parameter), $\sum \mathrm{CSR}_{\mathrm{d}}=$ the grand total of the monitored parameters, which is 26 . The mean of CSRD index was $22.3 \%$, deviation $17.99 \%$. Taking the 26 monitored parameters into consideration, this means an average of 5.8 parameters in a particular insurance company.

We intend to study CG through selected financial and non-financial determinants listed in Table 1. Our choice of determinants was based on the stakeholders' corporate governance model according to which the interests of all the groups involved should be taken into consideration for reason the shareholders are not the only risk bearers in the company [29]. Our research is focused on these interested parties: shareholders, management (members of boards), employees (executive staff and other employees), creditors and clients. In shareholders' model we will take into account the determinants for parties 1 and 2, in stakeholders' model we will calculate with all determinants.

Table 1: Financial and non-financial corporate governance determinants

\begin{tabular}{|c|c|c|}
\hline & Symbol & Description and measurement (interested parties' identifier) \\
\hline \multirow{12}{*}{ 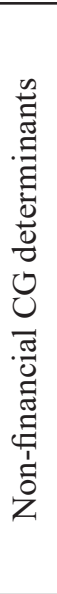 } & SHL & Percentage of first largest shareholder (1) \\
\hline & SHQ & Number of shareholders with qualified participation (1) \\
\hline & BDM & Total number of Board of Directors members (with chairman) (2) \\
\hline & BDW & Ratio of women in the Board of Directors (2) \\
\hline & BDUD & Ratio of the Board of Directors members with university degree (2) \\
\hline & $\mathrm{BDF}$ & Ratio of members in the Board of Directors with residence outside the Slovakia (2) \\
\hline & BSM & Total number of Board of Supervisors members (2) \\
\hline & BSW & Ratio of women in the Board of Supervisors (2) \\
\hline & BSUD & Ratio of the Board of Supervisors members with university degree (2) \\
\hline & BSF & Ratio of members in the Board of Supervisors with residence outside the Slovakia (2) \\
\hline & EMP & Total number of employees (3) \\
\hline & MAN & Ratio of middle managers on total number of employees (3) \\
\hline \multirow{10}{*}{ 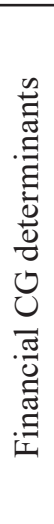 } & EQ & Equity (in EUR) (1) \\
\hline & NP & Net profit (in EUR) (1) \\
\hline & DR & Dividend ratio (dividend paid in 2017 / net profit for year 2016) (1) \\
\hline & BMRA & $\begin{array}{l}\text { Statutory, Executive and Supervisory Board members' remuneration (BMR) } \\
\text { (average per person, in EUR) (2) }\end{array}$ \\
\hline & GPW & Gross premium written (in EUR) (2) \\
\hline & $\mathrm{PC}$ & Total personnel costs (in EUR) (3) \\
\hline & LR & Loss ratio (Total gross claims paid / Total gross premium written) (3) \\
\hline & TI & Total indebtedness ((Assets-Equity)/Assets) (4) \\
\hline & LIQ & Liquidity (Receivables+Cash)/Creditors) (4) \\
\hline & GCP & Claims paid (gross amount in EUR) (5) \\
\hline
\end{tabular}

*(1) shareholders, (2) management, (3) employees, (4) creditors, (5) clients.

The impact of the selected CG determinants on CSR is identified with multiple linear regression analysis and through assembling the following linear regression model:

$$
\mathbf{y}=\beta_{0}+\beta_{1} x_{1}+\beta_{2} x_{2}+\cdots+\beta_{n} x_{n}+\varepsilon
$$

where: $y=$ an explained, dependent variable, $\beta=$ a regression coefficient, $x=$ a selected independent, explanatory variable, $\varepsilon=$ a random error, $\mathrm{n}=$ a number of explanatory variables. 
The relation of the CG determinants to CSRD index is established by means of the correlation analysis. We shall use Pearson's R and Somers' d $\left(\mathrm{H}_{0}: \rho=0 ; \mathrm{H}_{1}: \rho \neq 0\right)$. The explaining ability of the regression model is verified by $\mathrm{F}$ test ANOVA $\left(\mathrm{H}_{0}: \mu_{0}=\mu_{1}=\ldots=\mu_{\mathrm{n}} ; \mathrm{H}_{1}: \mu_{0} \neq \mu_{1} \neq \ldots \neq \mu_{\mathrm{n}}\right)$. Adequacy of the respective explanatory variables included in the model are evaluated with $\mathrm{T}$ test $\left(\mathrm{H}_{0}: \mu_{0}=\mu_{1} ; \mathrm{H}_{1}: \mu_{0} \neq \mu_{1}\right)$. To assess multicollinearity of the explanatory variables entering the regression model, we use the VIF (Variance Inflation Factor) indicator. Variables with VIF $<10$ can be assessed as weakly, insignificantly linearly interdependent. By means of Durbin-Watson test (DW) we assess residuals $\varepsilon_{\mathrm{i}}$ independence $\left(\mathrm{H}_{0}\right.$ : residuals $\varepsilon_{\mathrm{i}}$ are independent; $\mathrm{H}_{1}$ : residuals $\varepsilon_{\mathrm{i}}$ are interdependent). If required, this might by complement with a test of statistical relevance of the autocorrelation coefficient of the first degree for unstandardized and studentized residuals. For the purpose of assessment of the used statistical methods we use significance level $\alpha=0.1$.

\section{EMPIRICAL RESULTS AND DISCUSSION}

Table 2 shows the selected descriptive characteristics of all variables, whose impact on CSR was investigated for reason of their inclusion in regression models.

Table 2: Selected descriptive statistics

\begin{tabular}{|c|c|c|c|c|c|c|c|}
\hline \multirow{6}{*}{ 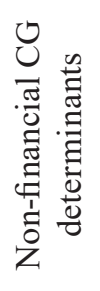 } & \begin{tabular}{|l|} 
Variables \\
\end{tabular} & SHL & SHQ & BDM & BDW & BDUD & BDF \\
\hline & Mean & 0.9312 & 1.5714 & 4.1333 & 0.2424 & 0.8867 & 0.2724 \\
\hline & Std. Deviation & 0.0941 & 0.6462 & 1.2459 & 0.2055 & 0.1807 & 0.3150 \\
\hline & Variables & BSM & BSW & BSUD & BSF & EMP & MAN \\
\hline & Mean & 5.3333 & 0.2125 & 0.5745 & 0.6354 & 396.0667 & 0.1228 \\
\hline & Std. Deviation & 3.1091 & 0.1810 & 0.3409 & 0.2698 & 441.5239 & 0.0677 \\
\hline \multirow{6}{*}{ 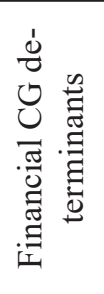 } & Variables & $\mathbf{E Q}$ & NP & DR & BMRA & GPW & PC \\
\hline & Mean & 77350533 & 10844133 & 0.6677 & 78000 & 137767353 & 10677200 \\
\hline & Std. Deviation & 96790802 & 18419591 & 0.5062 & 57752 & 170295624 & 12525258 \\
\hline & Variables & LR & TI & LIQ & GCP & & \\
\hline & Mean & 0.8923 & 0.8062 & 8.3670 & 78036533 & & \\
\hline & Std. Deviation & 1.1281 & 0.1141 & 24.9110 & 105583685 & & \\
\hline
\end{tabular}

Table 3 presents the results of the correlation analysis between the CSRD index and the examined independent variables. Calculations were performed in SPSS using Pearson' R and Somers'd, which measures the one - way dependence of variables. According to Somers'd, we found a strong negative correlation between CSRD index and SHQ, a weak negative correlation between CSRD index and BDF, BSUD and MAN, trivial in BSM, BSF, LR and LIQ. We identified positive dependence between the CSRD index and other variables. We identified statistically significant medium to strong dependence between CSRD and SHL, EMP, EQ, NP, DR, BMRA, GPW, PC and GCP.

Among the non-financial determinants of CG, BMRA and EMP have a significant positive effect on CSRD index and negative SHQ. From the financial determinants, with the CSRD index significantly positive correlate EQ, NP, DR, GPW, PC and GCP.

Table 4 presents the model summary results of a linear regression analysis of the impact of financial and non-financial CG determinants broken down by stakeholders. We performed the analysis in the SPSS program by enter and backward method. In the enter method, all variables are entered into the equation for relevant stakeholder group (see table 1). The backward method is a variable selection procedure in which the variable with the smallest partial correlation with the dependent variable is sequentially removed. 
Table 3: Correlation analysis of explanatory variables

\begin{tabular}{|c|c|c|c|c|c|c|c|}
\hline & & SHL & SHQ & BDM & BDW & BDUD & BDF \\
\hline \multirow{19}{*}{ 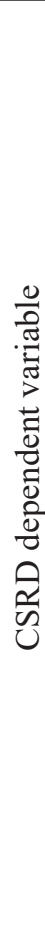 } & Pearson Corr. & .447 & $-.541^{* *}$ & .238 & -.028 & -.012 & -.289 \\
\hline & Sig. (2-tailed) & .109 & .046 & .394 & .921 & .967 & .296 \\
\hline & Somers' d & $.321^{*}$ & $-.564^{* * *}$ & .241 & .065 & .103 & -.256 \\
\hline & Sig. (2-tailed) & .080 & .001 & .220 & .796 & .743 & .197 \\
\hline & & BSM & BSW & BSUD & BSF & EMP & MAN \\
\hline & Pearson Corr. & -.128 & .189 & -.264 & .122 & $.628^{* *}$ & -.282 \\
\hline & Sig. (2-tailed) & .650 & .499 & .342 & .664 & .012 & .309 \\
\hline & Somers' d & -.012 & .220 & -.211 & -.069 & $.514^{* * *}$ & -.248 \\
\hline & Sig. (2-tailed) & .955 & .275 & .346 & .801 & .000 & .196 \\
\hline & & EQ & NP & DR & BMRA & GPW & PC \\
\hline & Pearson Corr. & $.563^{* *}$ & $.629^{* *}$ & .216 & $.849^{* * *}$ & $.616^{* *}$ & $.654^{* * *}$ \\
\hline & Sig. (2-tailed) & .029 & .012 & .440 & .000 & .014 & .008 \\
\hline & Somers'd & $.552^{* * *}$ & $.514^{* * *}$ & $.359^{*}$ & $.610^{* * *}$ & $.552^{* * *}$ & $.533^{* * *}$ \\
\hline & Sig. (2-tailed) & .000 & .000 & .078 & .000 & .000 & .000 \\
\hline & & LR & TI & LIQ & GCP & & \\
\hline & Pearson Corr. & -.229 & 292 & -.005 & $.490^{*}$ & & \\
\hline & Sig. (2-tailed) & .412 & .290 & .986 & .064 & & \\
\hline & Somers' d & -.019 & .190 & -.057 & $.590^{* * *}$ & & \\
\hline & Sig. (2-tailed) & .937 & .345 & .753 & .000 & & \\
\hline
\end{tabular}

${ }^{*}$ Correlation is significant at the 0.1 level (2-tailed). ${ }^{* *}$ Correlation is significant at the 0.05 level (2-tailed). ${ }^{* * *}$ Correlation is significant at the 0.01 level (2-tailed).

Table 4: Regression analysis for individual stakeholders

\begin{tabular}{|c|c|c|c|c|c|c|c|c|c|c|c|}
\hline \multirow{2}{*}{$\begin{array}{l}\stackrel{0}{Z} \\
\frac{0}{0} \\
\dot{0}\end{array}$} & \multirow{2}{*}{$\begin{array}{l}\frac{a}{0} \\
\frac{\pi}{0} \\
\frac{0}{0} \\
\frac{\pi}{\pi} \\
\frac{\pi}{2}\end{array}$} & \multirow{2}{*}{$\begin{array}{l}\text { : } \\
0 \\
\overline{0} \\
\sum\end{array}$} & \multirow[b]{2}{*}{ Predictors } & \multicolumn{5}{|c|}{ Model Summary } & \multicolumn{2}{|c|}{ ANOVA } & \multirow[b]{2}{*}{$\begin{array}{l}\text { Max. VIF } \\
\text { (var.) }\end{array}$} \\
\hline & & & & $\mathrm{R}$ & R Sq. & $\begin{array}{l}\text { Adj. R } \\
\text { Sq. }\end{array}$ & $\begin{array}{c}\text { Std. } \\
\text { Err. of } \\
\text { the Est. }\end{array}$ & DW & F value & Sig. & \\
\hline 1 & \multirow[t]{2}{*}{1} & $\mathrm{E}$ & $\begin{array}{l}\text { DR, SHQ, EQ, } \\
\text { SHL, NP } \\
\end{array}$ & .830 & .688 & .494 & .12482 & 1.618 & 3.534 & $.055^{*}$ & 4.78 (NP) \\
\hline 2 & & B & DR, SHQ, NP & .824 & .679 & .582 & .11335 & 1.765 & 7.043 & $.008^{* * *}$ & 1.10 (NP) \\
\hline 3 & \multirow{2}{*}{2} & E & $\begin{array}{l}\text { GPW, BDW, BSF, } \\
\text { BDUD, BSW, } \\
\text { BSM, BDF, BDM, } \\
\text { BMRA, BSUD } \\
\end{array}$ & .941 & .885 & .599 & .11391 & 1.241 & 3.093 & .144 & $\begin{array}{r}23.87 \\
\text { (BSUD) }\end{array}$ \\
\hline 4 & & B & \begin{tabular}{|l|} 
GPW, BDW, \\
BDUD, BSW, \\
BSM, BDF, BDM, \\
BMRA, BSUD \\
\end{tabular} & .941 & .885 & .679 & .10189 & 1.242 & 4.296 & $.062^{*}$ & 8.35 (GPW) \\
\hline 5 & \multirow[t]{2}{*}{3} & E & $\begin{array}{l}\text { LR, EMP, MAN, } \\
\text { PC }\end{array}$ & .683 & .466 & .253 & .15551 & 1.745 & 2.185 & .144 & 21.77 (EMP) \\
\hline 6 & & $\mathrm{~B}$ & LR, MAN, PC & .681 & .463 & .317 & .14871 & 1.718 & 3.165 & $.068^{*}$ & $1.12(\mathrm{PC})$ \\
\hline 7 & \multirow[t]{2}{*}{4} & E & LIQ, TI & .297 & .088 & -.064 & .18556 & 1.691 & .582 & .574 & $\begin{array}{r}1.03(\mathrm{TI}, \\
\text { LIQ) }\end{array}$ \\
\hline 8 & & $\mathrm{~B}$ & TI & .292 & .086 & .015 & .17856 & 1.653 & 1.216 & .290 & 1.000 \\
\hline 9 & 5 & $E$ & GCP & .490 & .240 & .181 & .16282 & 1.676 & 4.097 & $.064^{*}$ & 1.000 \\
\hline
\end{tabular}

${ }^{*}$ Correlation is significant at the 0.1 level (2-tailed). ${ }^{* *}$ Correlation is significant at the 0.05 level (2-tailed). ${ }^{* * *}$ Correlation is significant at the 0.01 level (2-tailed). ${ }^{a}$ (1) shareholders, (2) management, (3) employees, (4) creditors, (5) clients. ${ }^{b}$ E - enter (all explanatory variables), B - backward (the best significant model). 
We evaluated the models No. 1, 2, 4, 6 and 9 as significant, all predictors in these models having VIF $<10$ and the models showing residual independence. According to Adj. R Square has the best denomination model number 4 , which contains determinants representing the influence of managing authorities on CSRD. In this model, there is a strong correlation ( $\mathrm{R}=94.1 \%)$ between CSRD index and explanatory variables. With this model, we can explain $88.5 \%$ of the CSRD index variability, Adj. R Square is $67.9 \%$. Autocorrelation coefficient for unstandardized residuals is 0.11 and critical value is 0.328 , therefore the residuals are independent. However, model 4 contains only one statistically significant variable (BMRA). The regression coefficients of the variables in models 1, 2, 4, 6 and 9 are shown in Table 5.

Table 5: Regression coefficients for selected stakeholders modelsa

\begin{tabular}{|c|c|c|c|c|c|c|c|}
\hline & \multirow[t]{2}{*}{ Models } & \multicolumn{2}{|c|}{ Unstandardized Coefficients } & $\begin{array}{c}\text { Standardized } \\
\text { Coefficients }\end{array}$ & \multirow[t]{2}{*}{$\mathrm{t}$} & \multirow[t]{2}{*}{ Sig. } & $\begin{array}{c}\text { Collinearity } \\
\text { Statistics }\end{array}$ \\
\hline & & $\mathrm{B}$ & Std. Error & Beta & & & VIF \\
\hline \multirow{6}{*}{1} & (Constant) & .043 & .568 & &, 075 & ,942 & \\
\hline & SHL & .232 & .509 & .125 & .456 & .660 & 1.915 \\
\hline & SHQ & -.102 & .072 & -.374 & -1.415 & .195 & 1.796 \\
\hline & EQ & $-1.976 \mathrm{E}-10$ & .000 & -.112 & -.265 & .798 & 4.573 \\
\hline & NP & $6.743 \mathrm{E}-09$ & .000 & .730 & 1.691 & .129 & 4.780 \\
\hline & DR & .110 & .078 & .308 & 1.422 & .193 & 1.201 \\
\hline \multirow{4}{*}{2} & (Constant) & .295 & .103 & & 2.855 & $.017^{* *}$ & \\
\hline & SHQ & -.124 & .049 & -.456 & -2.519 & $.030^{* *}$ & 1.019 \\
\hline & NP & $5.927 \mathrm{E}-09$ & .000 & .641 & 3.418 & $.007^{* * *}$ & 1.096 \\
\hline & DR & .098 & .067 & .274 & 1.474 & .171 & 1.076 \\
\hline \multirow{10}{*}{4} & (Constant) & -.225 & .261 & & -.864 & .427 & \\
\hline & BDM & .077 & .048 & .530 & 1.581 & .175 & 4.910 \\
\hline & BDW & .501 & .271 & .572 & 1.848 & .124 & 4.182 \\
\hline & BDUD & -.076 & .221 & -.077 & -.346 & .743 & 2.148 \\
\hline & BDF & .060 & .126 & .104 & .474 & .655 & 2.110 \\
\hline & BSM & -.027 & .023 & -.471 & -1.211 & .280 & 6.610 \\
\hline & BSW & .035 & .194 & .035 & .178 & .866 & 1.658 \\
\hline & BSUD & -.024 & .116 & -.045 & -.204 & .846 & 2.127 \\
\hline & BMRA & $3.098 \mathrm{E}-06$ & .000 & .994 & 2.696 & $.043^{* *}$ & 5.939 \\
\hline & GPW & $-2.027 \mathrm{E}-10$ & .000 & -.192 & -.439 & .679 & 8.353 \\
\hline \multirow{4}{*}{6} & (Constant) & .202 & .113 & & 1.793 & $.100^{*}$ & \\
\hline & MAN & -.380 & .622 & -.143 & -.612 & .553 & 1.120 \\
\hline & $\mathrm{PC}$ & $8.490 \mathrm{E}-09$ & .000 & .591 & 2.524 & $.028^{* *}$ & 1.124 \\
\hline & LR & -.026 & .036 & -.160 & -.703 & .497 & 1.061 \\
\hline \multirow{2}{*}{9} & (Constant) & .158 & .053 & & 2.985 & $.011^{* *}$ & \\
\hline & GCP & $8.342 \mathrm{E}-10$ & .000 & .490 & 2.024 & $.064^{*}$ & 1.000 \\
\hline
\end{tabular}

${ }^{a}$ Dependent Variable: CSRD. ${ }^{*}$ Correlation is significant at the 0.1 level (2-tailed). ${ }^{* *}$ Correlation is significant at the 0.05 level (2-tailed). ${ }^{* * *}$ Correlation is significant at the 0.01 level (2-tailed).

We were also interested in the impact of the explanatory variables broken down by financial and non-financial CG determinants (see Table 1). The analysis results are presented in Table 6. The variables are selected by the backward method. We consider both models to be significant. Non-financial determinants explain the higher proportion of CSRD index variability $(95.4 \%)$ as a financial determinant of CG that explains $88.5 \%$ of the CSRD index variability. Residuals are independent in both models. 
Table 6: Regression analysis for financial and non-financial CG determinants

\begin{tabular}{|c|c|c|c|c|c|c|c|c|c|}
\hline \multirow{2}{*}{$\begin{array}{l}0 \\
\frac{0}{0} \\
\frac{0}{0} \\
\sum\end{array}$} & \multirow{2}{*}{ 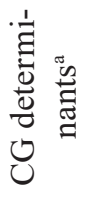 } & \multirow[b]{2}{*}{ Predictors } & \multicolumn{5}{|c|}{ Model Summary } & \multicolumn{2}{|c|}{ ANOVA } \\
\hline & & & $\mathrm{R}$ & R Square & $\begin{array}{l}\text { Adj. R } \\
\text { Square }\end{array}$ & $\begin{array}{l}\text { Std. Err. } \\
\text { of the } \\
\text { Est. }\end{array}$ & $\begin{array}{l}\text { Durbin } \\
\text {-Watson }\end{array}$ & $\mathrm{F}$ value & Sig. \\
\hline 10 & $\mathrm{~N}$ & $\begin{array}{l}\text { MAN, SHL, BDUD, } \\
\text { BDM, BDW, BSUD, } \\
\text { BSW, BSM }\end{array}$ & .991 & .982 & .954 & .03773 & 1.890 & 34.488 & $.001^{* * * *}$ \\
\hline 11 & $\mathrm{~F}$ & $\begin{array}{l}\text { TI, DR, EQ, BMRA, } \\
\text { PC }\end{array}$ & .962 & .926 & .885 & .06096 & 1.696 & 22.596 & $.000^{* * *}$ \\
\hline
\end{tabular}

${ }^{*}$ Correlation is significant at the 0.1 level (2-tailed). ${ }^{* *}$ Correlation is significant at the 0.05 level (2-tailed). *** Correlation is significant at the 0.01 level (2-tailed). ${ }^{a} F$ - financial, $N$-non-financial.

The regression coefficients for models 10 and 11 are shown in Table 7. The results show that all non-financial predictors included in model 10 are significant. In the model 11 for selected financial predictors, there are DR and BMRA significant.

Table 7: Regression coefficients for financial and non-financial CG determinantsa

\begin{tabular}{|c|c|c|c|c|c|c|c|}
\hline \multirow{2}{*}{\multicolumn{2}{|c|}{ Models $^{\mathrm{b}}$}} & \multicolumn{2}{|c|}{ Unstandardized Coefficients } & \multirow{2}{*}{$\begin{array}{c}\begin{array}{c}\text { Standardized } \\
\text { Coefficients }\end{array} \\
\text { Beta } \\
\end{array}$} & \multirow[t]{2}{*}{$\mathrm{t}$} & \multirow[t]{2}{*}{ Sig. } & \multirow{2}{*}{$\begin{array}{c}\text { Collinearity } \\
\text { Statistics }\end{array}$} \\
\hline & & $\mathrm{B}$ & Std. Error & & & & \\
\hline \multirow{9}{*}{10} & (Constant) & .533 & .182 & & 2.922 & $.033^{* *}$ & \\
\hline & \begin{tabular}{|l|} 
SHL \\
\end{tabular} & .872 & .142 & .468 & 6.131 & $.002^{* * *}$ & 1.635 \\
\hline & BDM & .124 & .015 & .896 & 8.120 & $.000^{* * * *}$ & 3.420 \\
\hline & BDW & .583 & .084 & .670 & 6.897 & $.001^{* * *}$ & 2.649 \\
\hline & BDUD & -.986 & .092 & -.947 & -10.695 & $.000^{* * *}$ & 2.202 \\
\hline & BSM & -.057 & .007 & -.987 & -7.934 & $.001^{* * *}$ & 4.345 \\
\hline & BSW & -.564 & .091 & -.594 & -6.224 & $.002^{* * *}$ & 2.556 \\
\hline & \begin{tabular}{|l|} 
BSUD \\
\end{tabular} & -.163 & .049 & -.318 & -3.296 & $.022^{* *}$ & 2.618 \\
\hline & MAN & -2.920 & .260 & -1.111 & -11.240 & $.000^{* * * *}$ & 2.742 \\
\hline \multirow{6}{*}{11} & (Constant) & -.238 & .120 & & -1.984 & $.079^{*}$ & \\
\hline & EQ & $-9.215 \mathrm{E}-10$ & .000 & -.496 & -1.823 & .102 & 9.022 \\
\hline & DR & .172 & .037 & .484 & 4.698 & $.001^{* * *}$ & 1.294 \\
\hline & BMRA & $2.908 \mathrm{E}-06$ & .000 & .933 & 5.398 & $.000^{* * * *}$ & 3.646 \\
\hline & PC & 6.147E-09 & .000 & .428 & 1.267 & .237 & 13.902 \\
\hline & TI & .156 & .148 & .099 & 1.052 & .320 & 1.073 \\
\hline
\end{tabular}

Taking the results of these tests into account, we will formulate the following regression function, which the best explaining the CSRD index:

$$
\begin{aligned}
C S R D \text { index }= & 0.533+0.872 S H L+0.124 B D M+0.583 B D W-0.986 B D U D \\
& -0.057 B S M-0.564 B S W-0.163 B S U D-2.920 M A N+\varepsilon
\end{aligned}
$$

In this model, the strongest correlation $(\mathrm{R}=99.1 \%)$ is between the CSRD and the explanatory variables from all the models examined. $95.4 \%$ of the CSRD index variability can be explained by model containing non-financial CG determinants. This model is significant at 0.01 level. The results show a positive dependence between CSRD and SHL, BDM and BDW. Negative dependence is identified between CSRD and BDUD, BSUD, BSM, BSW and MAN. 


\section{CONCLUSION}

Insurance companies do not sufficiently present their CSR activities in their annual reports. They only provide information on supported areas. They also do not mention the volume of funds provided. In order to model CSR, we found that the predictors describing managing authorities (2) and shareholders (1) could provide the best explanation. By comparing the models made up of predictors divided into financial and non-financial CG determinants, we found that CSR better explain non-financial parameters.

\section{ACKNOWLEDGEMENT}

This paper has been supported by the Scientific Grant Agency of Slovak Republic under project VEGA No. 1/0749/18 „Research on the application of corporate governance principles in companies in Slovakia". The authors would like to express their gratitude to the Scientific Grant Agency of The Ministry of Education, Science, Research and Sport of the Slovak Republic for financial support of this research and publication.

\section{REFERENCES}

[1] Act on Insurance No. 39/2015 and amending certain acts.

[2] Adams, R. B. (2012) Governance and the financial crisis, International Review of Finance, (12)1, pp. 7-38.

[3] Akbar, S., Poletti-Hughes, J., El-Faitouri, R., Zulfiqar, S. and Shah, A. (2016) More on the relationship between corporate governance and firm performance in the UK: Evidence from the application of generalized method of moments estimation, Research in International Business and Finance, Vol. 38, pp. 417-429.

[4] Ararat, M., Black, B. S., Yurtoglu, B. B. (2017) The effect of corporate governance on firm value and profitability: Time-series evidence from Turkey, Emerging Markets Review, Elsevier, Vol. 30, pp. 113-132.

[5] Bartkowiak, P., Borkowski, M. (2014) Financial review as an element of corporate governance in the Polish legal regulations, Journal of International Studies, (7)2, 2014, pp. 70-82.

[6] Beltratti, A., Stulz, R. M. (2012) The credit crisis around the globe: Why did some banks perform better?, Journal of Financial Economics, (105)1, pp. 1-17.

[7] Benetti, K. (2019) Strategic CSR: the Importance of the CSR Filter, Proceedings of the 12th International Scientific Conference European Forum of Entrepreneurship 2019“, Sustainable Socio-economic Development or Crisis on the Horizon?", pp. 27-36.

[8] Bowen, H. R. (1953) Social Responsibilities of the Businessman, Harper Brothers, New York, $276 \mathrm{p}$.

[9] Cadbury, A. (2002) Corporate governance and chairmanship: a personal view, OUP Oxford, $280 \mathrm{p}$.

[10] Cadbury, A. (1992) Report of the Committee on the Financial Aspects of Corporate Governance, Gee \& Co. Ltd., London.

[11] Carroll, A. B., Shabana, K. M. (2010) The business case for corporate social responsibility: a review of concepts, research and practice, International Journal of Management Reviews, 12 (1), pp. 85-105.

[12] Commission of the European Communities. (2001) Green Paper: Promoting a European Framework for Corporate Social Responsibility, [online], Brussel, 2001 [cit. 2019-5-5], Available on: http://europa.eu/rapid/press-release_DOC-01-9_en.htm, pp. 37. 
[13] Elkington, J. (1998) Cannibals With Forks: The Triple Bottom Line of 21st Century Business. New Society Publishers, Stony Creek, 416 p.

[14] Fooladi, M., Zaleha, A. S., Norman, M. S., Romlah, J. (2014) The effect of corporate governance and divergence between cash flow and control rights on firm performance: Evidence from Malaysia, International Journal of Disclosure and Governance, Vol. 11(4), pp. 326-340.

[15] G20/OECD Principles of Corporate Governance. Retrieved February 2, 2019, Available on: http://www.oecd.org/corporate/principles-corporate-governance.htm.

[16] Grofčíková, J. (2017) Impact of globalization on the financial management processes, Globalization and its socio-economic consequences, 17th international scientific conference, Žilina, Slovakia, pp. 589-596.

[17] Grofčíková, J. (2016) Globalization and its impact on the corporate financial management and control, Globalization and its socio-economic consequences, 16th International Scientific Conference, Proceedings Part II, Žilina, Slovakia, pp. 547-555.

[18] Grofčíková, J., Izáková, K. (2018) Corporate governance and firm performance in Slovakia, Globalization and its socio-economic consequences, 18th International Scientific Conference, Rajecké Teplice, Slovakia, pp. 532-539.

[19] Halim, E. H., Mustika, G., Sari, R. N., Anugerah, R., \& Mohd-Sanusi, Z. (2017) Corporate governance practices and financial performance: The mediating effect of risk management committee at manufacturing firms, Journal of International Studies, 10(4), pp. 272-289.

[20] Hučka, M., Malý, M., Okruhlica F. (2007) Správa společností, Kernberg Publishing, Praha, $276 \mathrm{p}$.

[21] Millstein, I. M. (1998) Corporate governance: Improving competitiveness and access to capital in global markets: a report to the OECD, Institutional investors, corporate governance and firm performance in Japan, Pacific Economic Review, 15(5), pp. 653-665.

[22] Mullerat, R. (2010) International Corporate Social Responsibility: The Role of Corporations in the Economic Order of the 21st Century, Kluwer Law International, Alphen aan den Rijn, 510 p.

[23] Musa, H., Musová, Z., Debnárová, L. (2014) Responsibility in the corporate governance framework and financial decision making process, Elsevier, Amsterdam, Vol. (23), pp. 1023-1029.

[24] Norman, W., \& MacDonald, C. (2004) Getting to the Bottom of "Triple Bottom Line", Business Ethics Quarterly, 14(2), pp. 243-262.

[25] Procházka, D. (2017) The impact of ownership and other corporate characteristics on performance of V4 companies, Journal of International Studies, 10(2), pp. 204-218.

[26] Ricci, O. (2014) Corporate Governance in the European Insurance Industry, Palgrave Macmillan, Basingstroke, $154 \mathrm{p}$.

[27] Shleifer, A., Vishny, R. W. (1997) A Survey of Corporate Governance. Journal of Finance, (52)2, pp. 737-783.

[28] Škare, M., Hasić, T. (2015) Corporate governance, firm performance and economic growth - theoretical analysis, Journal of Business Economics and Management, 17(1), pp. 35-51.

[29] Vo, D., Phan, T. (2013) Corporate governance and firm performance: Empirical Evidence from Vietnam, Journal of Economic Development, Vol. 2018, pp. 62-77.

[30] Vu, N. H., Nguyen, T. (2017) Impacts of corporate governance on firm performance, Empirical study of listed Singaporean companies, [Online], Lund University, Available on: https://lup.lub.lu.se/student papers/search/publication/8917364.

[31] Zahroh, N., Hamidah. (2016) The Role of Corporate Governance in Firm Performance, SHS Web of Conferences 34, 13003(2017), 6 p. 